\title{
発色団を有する大環状シッフ塩基配位子の銅イオン流れ 分析系への応用
}

\author{
藤原 学, 松下隆之* ${ }^{*}$, 山庄司由子 ${ }^{\circledR}$, 森田 徹, \\ 谷 晴仁, 田中 稔, 庄野 利之**
}

(1990 年 12 月 11 日受理)

\begin{abstract}
発色団を有する新規な大環状テトラアザシッフ塩基配位子 $\mathrm{L}_{1}$ 並びに $\mathrm{L}_{2}$ を合成し，銅（II）イオンと の錯形成条件を検討した， $\mathrm{L}_{1}$ は $\mathrm{L}_{2}$ に比較して，銅(II) イオンに対して高い選択性を示し，生成する 錯体の安定性に優れ, 高いモル吸光係数（ $\log \varepsilon=4.22 ）$ を有しているので, 銅(II) イオンの定量試薬 として流れ分析系に応用した。通常の並列流路方式とマージングゾーン法両方で検討した結果, 前法で は十分に錯形成が行われていないようで定量濃度域も低いが, 後法では, 最適条件下で得られた検量線 の傾きが, バッチ法とほぼ同じであったことから，錯形成も十分であると考えられた。マージングゾー ン法を用いることによりバッチ法とほぼ同等の精度で銅(II) イオンの定量が可能であり, 又, バッチ 法で大きく妨害したニッケル(II) イオンの影響が軽減された。
\end{abstract}

\section{1 緒言}

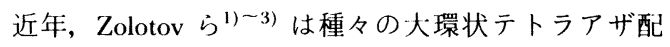
位子を合成しこれらを用いる遷移金属イオンの溶媒抽 出においては銅(II) イオンに対して優れた選択性を示 すことを報告している．著者らも銅(II) イオンに対し て優れた選択性を有する大環状テトラアザ配位子に電子 吸引性のニト口基を導入することによって, 環内の $\mathrm{NH}$ プロトンの解離を促進し, 金属イオンとの錯形成反応を 高めることに成功し，それらを用いる銅（II）イオンの 吸光光度試薬並びに選択的分離剤への応用を報告し $た^{(4)-8)}$. 銅(II) イオンの吸光光度試薬として高いモル 吸光係数を有するポルフィリン誘導体を用いた研究 (例9) 12)が多く報告されているが，これらは高感度であ る反面，一般に錯形成速度が小さいという久点がある. 本報では, 2 種類の大環状テトラアザ配位子に 7-クロロ4-ニトロベンゾ-2-オキサ-1,3-ジアゾールを反応させて得 た新しいタイプの環状シッフ塩基配位子 $\mathrm{L}_{1}, \mathrm{~L}_{2}$ を合成 し，銅（II）イオンとの錯生成反応を検討した。その結 果, 錯体生成速度も大きく, 生成錯体の安定性もよい, 6,13-ビス(4'-ニトロベンゾ-2'-オキサ-1',3'-ジアゾイル-

* 龍谷大学理工学部: 520-01 滋賀県大津市瀬田大江町 横谷 1-5

** 大阪大学工学部：565 大阪府吹田市山田丘 2-1
5,7,12,14-テトラメチル-1,4,8,11-テトラアザシクロテト ラデカ-4,6,11,13-テトラエン, $\mathrm{L}_{1}$ を銅 (II) イオンの吸 光光度試薬として, 流れ分析系 (FIA 法) へ応用し た. バッチ法では発色反応が平衡に達した後, 測定する のが普通であるが，FIA 法では流量と反忘コイルの長 さを調節することによって, 反忘時間を厳密に調節する ことができる．FIA 法に応用した結果，バッチ法と比 較して同等の感度と定量濃度域が得られ，バッチ法で銅 （II）イオンの定量を妨害したニッケル（II）イオンの影 響が軽減されるという良好な結果が得られたので報告す る.

\section{2 実験}

\section{$2 \cdot 1$ 配位子並びに銅錯体の合成}

本実験で新しく合成した環状テトラアザ配位子の合成 経路を Fig. 1 に示す.

2・1・1 $\mathbf{L}_{\mathbf{1}}$ の合成＼cjkstart文献記載の方法 ${ }^{13)}$ に準じて合 成した 5,7,12,14-テトラメチル-1,4,8,11-テトラアザシク ロテトラデカ-4,6,11,13-テトラエン $0.40 \mathrm{~g}(1.6 \mathrm{mmol})$ を脱水アセトニトリルに加熱溶解し，7-クロロ-4-ニトロ ベンゾ-2-オキサ-1,3-ジアゾール $0.32 \mathrm{~g}(1.6 \mathrm{mmol})$ の脱 水アセトニトリル溶液を $50^{\circ} \mathrm{C}$ で徐々に滴下した，滴下 之同時に白色沈殿を生ずるが，更にかき混ぜ続けると濃 青色の溶液となる. 滴下終了後加熱を止め, 室温で約 2 


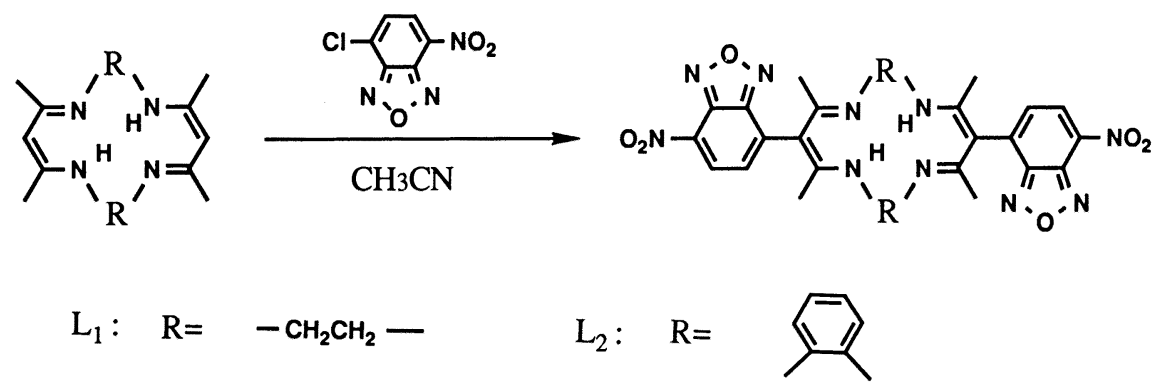

Fig. 1 Synthesis of ligands

時間かき混ぜた。 反応終了後水冷し，析出した沈殿を沃 別し，化合物 $\mathrm{L}_{1}$ を得た。 アセトニトリルより再結晶し た紫色針状結晶 $(0.2 \mathrm{~g}$, 収率 $35 \%)$ は IR スペクトル， マススペクトル $\left(\mathrm{M}^{+} 574\right)$ 並びに元素分析値 $\{54.1 \% \mathrm{C}$, $4.5 \% \mathrm{H}, 24.3 \% \mathrm{~N}$; 計 算 值 $\left(\mathrm{C}_{26} \mathrm{H}_{26} \mathrm{~N}_{10} \mathrm{O}_{6}\right)$ : $54.4 \% \mathrm{C}, 4.6 \% \mathrm{H}, 24.4 \% \mathrm{~N}\}$ により確認, 同定した.

$\mathbf{2 ・ 1 ・ 2} \mathbf{L}_{\mathbf{2}}$ の合成文献記載の方法 ${ }^{14)}$ に準じて合 成した 6,18,15,17-テトラメチル-ジベンゾ-5,9,14,18-テト ラアザシクロテトラデセン $0.1 \mathrm{~g}(0.29 \mathrm{mmol})$ を脱水し たアセトニトリル $30 \mathrm{ml}$ に加熱溶解し，これに $0.12 \mathrm{~g}$ (0.58 mmol) の 7-クロロ-4-ニトロベンゾ-2-オキサ-1,3ジアゾールのアセトニトリル溶液 $10 \mathrm{ml} 50^{\circ} \mathrm{C}$ でゆっ くり滴下した. 滴下終了後更に 2 時間還流した. 反忘 終了後析出した沈殿を沃別し, エーテルと石油エーテル で洗浄し，化合物 $\mathrm{L}_{2}$ を得た。 ベンゼンより再結晶した 紫色針状結晶（0.04 g 収率 $20 \%)$ は, IR 並びにマスス ペクトル $\left(\mathrm{M}^{+} 670\right)$ と元素分析值 $\{61.6 \% \mathrm{C}, 4.3 \% \mathrm{H}$, $20.0 \% \mathrm{~N}$; 計算值 $\left(\mathrm{C}_{34} \mathrm{H}_{26} \mathrm{~N}_{10} \mathrm{O}_{6}\right) \quad 60.9 \% \mathrm{C}, 3.9 \% \mathrm{H}$, $20.9 \% \mathrm{~N}\}$ により確認した.

2・1・3 銅錯体の合成銅錯体は配位子と等モル量 の酢酸銅を DMF 中, $80^{\circ} \mathrm{C}$ で 2 時間反応させることに よって得た. $\mathrm{CuL}_{1}$ はアセトニトリル, $\mathrm{CuL}_{2}$ はDMF よりそれぞれ再結晶した。元素分析值 $\mathrm{CuL}_{1}\{48.7 \% \mathrm{C}$, $4.1 \% \mathrm{H}, 21.6 \% \mathrm{~N}$ : 計算值 $\left(\mathrm{C}_{26} \mathrm{H}_{24} \mathrm{~N}_{10} \mathrm{O}_{6} \mathrm{Cu}\right): 49.1 \%$ $\mathrm{C}, 3.8 \% \mathrm{H}, 22.0 \% \mathrm{~N}\}, \mathrm{CuL}_{2}\{55.5 \% \mathrm{C}, 3.4 \% \mathrm{H}, 18.7 \%$ $\mathrm{N}$ : 計算值 $\left(\mathrm{C}_{34} \mathrm{H}_{24} \mathrm{~N}_{10} \mathrm{O}_{6} \mathrm{Cu}\right) 55.8 \% \mathrm{C}, 3.3 \% \mathrm{H}, 19.1 \%$ N\}

\section{$\mathbf{2} \cdot \mathbf{2}$ 試 薬}

銅 (II) イオン水溶液: 酢酸銅一水和物（和光純薬工 業) $0.200 \mathrm{~g}$ を精ひょうし, $1 \mathrm{M}\left(1 \mathrm{M}=1 \mathrm{~mol} \mathrm{dm}^{-3}\right)$ 塩 酸水溶液に溶解し, 水で希釈して全容を $100 \mathrm{ml}$ $\left(1 \times 10^{-2} \mathrm{M}\right)$ とし，これを適宜希釈して用いた。
緩衝液: 適当な $\mathrm{pH}$ に調整した $0.1 \mathrm{M}$ 酢酸一酢酸ナト リウム緩衝液を 10 倍に希釈して使用した.

DMF は市販特級品を 2 度減圧蒸留して用いた。その 他の試薬はいずれも市販特級品を用いた。

\section{$2 \cdot 3$ 装}

分光光度計：吸収スペクトルの測定には日立 340 型 自記分光光度計を用い, 七ルは光路長 $1 \mathrm{~cm}$ のものを用 いた。

pHメーター：堀場 F-8 DP 型を用いた。

FIA 装置: 日本分光 FIU-300 型フローインジェクシ ヨンシステムと内径 $0.5 \mathrm{~mm}$ のテフロンチューブを用い た. 検出器には日本分光 Ubest-30 型ダブルビーム分光 光度計に FIC-361 型フローセルを取り付けて使用し た.

\section{$2 \cdot 4$ 実呤㨲作}

2・4・1 錯形成率の測定 配位子 $\mathrm{L}_{1}$ 又は $\mathrm{L}_{2}$ の DMF 溶液 $\left(5 \times 10^{-5} \mathrm{M}\right)$ に等モル量の酢酸銅一水和物 の DMF 溶液を加え, $25^{\circ} \mathrm{C}$ において一定時間ごとに吸 収スペクトルを測定し, 錯形成率を求めた。

\section{2・4・2 バッチ法における銓(II) イオンの定盘操作及} び共存イオンの影䈏 配 位子 $\mathrm{L}_{1}$ の DMF 溶液 $\left(6.25 \times 10^{-5} \mathrm{M}\right) 8 \mathrm{ml}$ を $10 \mathrm{ml}$ メスフラスコにとり,こ れに酢酸-酢酸ナトリウム緩衝液で $\mathrm{pH} 4.1$ に調製した 各種濃度の銅 (II) イオン水溶液 $1 \mathrm{ml}$ を加えた後,

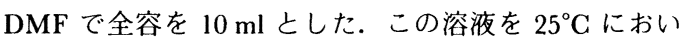
て 10 分間放置した後, $760 \mathrm{~nm}$ における吸光度を試薬 から試験液に対して測定し，検量線を作成した。又，銅 （II）イオン $\left(5 \times 10^{-5} \mathrm{M}\right)$ と同濃度の共存イオンを添 加して同様に吸光度を測定し，定量に及ぼす影響を求め た.

2・4・3 FIA 操作 Fig. 2 に用いた FIA システム Type I と Type II を示す. Type I は試薬の溶液を常時 


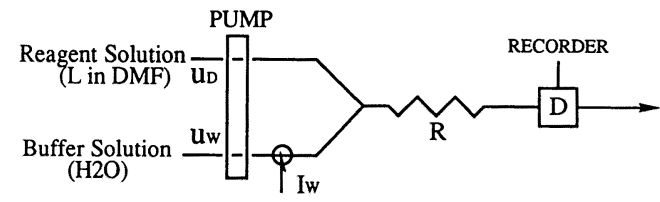

Type I

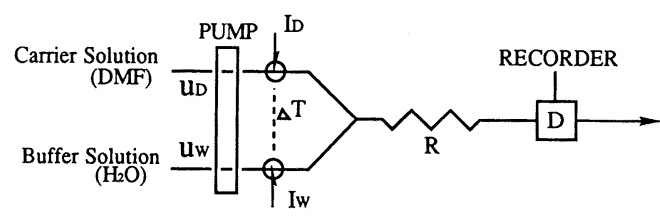

Type II

UD, Uw: Flow rate; ID, Iw: Injection volume $\triangle T$ : Difference of injection time; $R$ : Length of reaction coil; D: UV Detector

Optimum conditions for Type I:

UD: $0.5 \mathrm{ml} / \mathrm{min}$; Uw: $0.16 \mathrm{ml} / \mathrm{min} ; \mathrm{Iw}: 50 \mu \mathrm{l} ; \mathrm{R}$ : $200 \mathrm{~cm} ; \mathrm{D}:$ UV Detector $(760 \mathrm{~nm})$

Optimum conditions for Type II are shown in Table 1.

Fig. 2 Flow systems (Type I and II)

送液しながら試料溶液（金属イオン）を注人する通常の 並列流路方式であり, Type II は試薬も試料溶液も同時 に注入し，混合する方式 (マージングゾーン法)であ る.

\section{3 結果亡考察}

\section{$3 \cdot 1$ 錯体の吸収スペクトル}

金属イオンの吸光光度定量に用いる試薬としては, 生 成した金属錯体のモル吸光係数が大きく，かつ錯体生成 に伴う吸収帯の大きなシフトが必要である，更に試薬と 金属イオンとの錯生成速度が大きいことが望まれる．以 下これらの条件について検討した。配位子 $\mathrm{L}_{1}$ 並びに $\mathrm{L}_{2}$ とそれらの銅錯体の DMF 溶液中での吸収スペクト ルを Fig. 3 及び Fig. 4 にそれぞれ示す. 配位子 $\mathrm{L}_{1}$ は 共役二重結合に直接発色団を導入したために, 高度に共 役系が伸び, 吸収極大波長 $620 \mathrm{~nm}(\log \varepsilon=4.21)$ に強 い吸収帯を有している。これが銅イオンと錯形成するこ とにより, 吸収極大波長 $733 \mathrm{~nm}(\log \varepsilon=4.22)$ と大き く長波長シフトして強度も比較的大きい吸収帯となる. この大きな吸収帯のシフトは, 銅(II) イオンの存在す る環内の共役系と発色団が共役しているためと考えられ る. 環骨格の吸収帯は $308 \mathrm{~nm}$ 付近に存在し, $620 \mathrm{~nm}$ の吸収帯より強度は高いが, 生成した銅錯体の吸収帯と
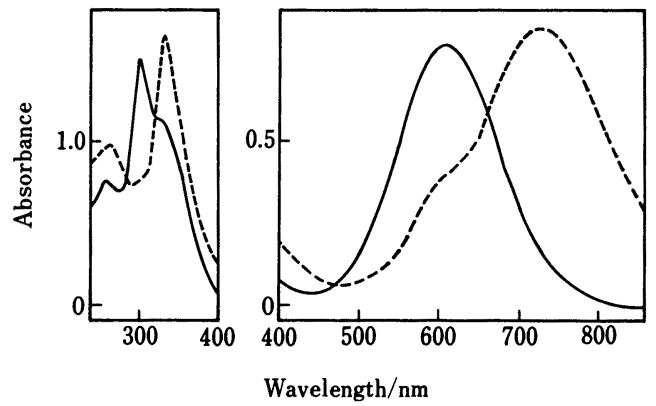

Fig. 3 Absorption spectra of $\mathrm{L}_{1}$ and $\mathrm{CuL}_{1}$ in DMF

$(\longrightarrow): \mathrm{L}_{1} ;(---): \mathrm{CuL}_{1}$; Concentration of $\mathrm{L}_{1}$ and $\mathrm{CuL}_{1}: 5 \times 10^{-5} \mathrm{M}$

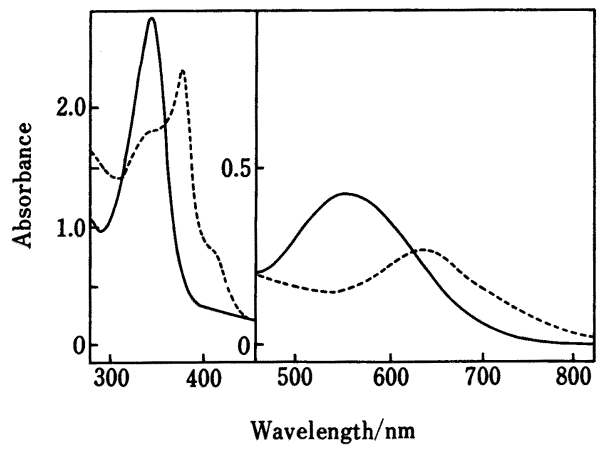

Fig. 4 Absorption spectra of $\mathrm{L}_{2}$ and $\mathrm{CuL}_{2}$ in DMF

$(-): \mathrm{L}_{2} ;(---)$ : $\mathrm{CuL}_{2}$; Concentration of $\mathrm{L}_{2}$ and $\mathrm{CuL}_{2}: 5 \times 10^{-5} \mathrm{M}$

重なるために, 高い感度が得られない, 一方, 配位子 $\mathrm{L}_{2}$ 及びその錯体の吸収極大波長は $\mathrm{L}_{1}$ 及びその銅錯体 に比べて，それぞれ短波長側にあり，強度もかなり減少 している（配位子 $\mathrm{L}_{2}$ 吸収極大波長 $=552 \mathrm{~nm}, \log \varepsilon=$ $3.93, \mathrm{CuL}_{2}$ 錯体吸収極大波長 $=636 \mathrm{~nm}, \log \varepsilon=3.71$ )

(Fig. 4).これは架橋ジアミンがフェニレン環を有して おり，環骨格の共役系が拡大するものの，平面的でリジ ッドなテトラアザ環となり, 発色団との共役の度合がむ しろ弱まったためと考えられる.これらの結果より，銅 （II）イオンと錯形成することにより大きく長波長シフ トする配位子 $\mathrm{L}_{1}$ が銅(II) イオンの定量試薬としてよ り有効であると考えられる.なお，銅錯体の吸収極大波 長は $733 \mathrm{~nm}$ であるが，配位子の妨害が少なく銅錯体の 生成により吸収強度の増大が最も大きい $760 \mathrm{~nm}$ を測定 波長とした。 


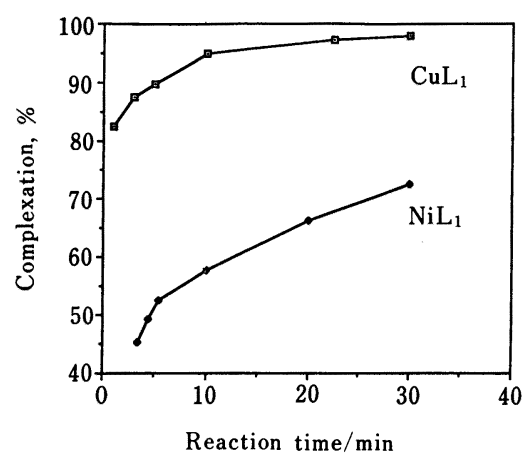

Fig. 5 Time courses of complexation of $\mathrm{L}_{1}$ with copper(II) and nickel(II) in DMF solution at $25^{\circ} \mathrm{C}$ Concentration of $\mathrm{L}_{1}$, copper(II) and nickel(II): $5 \times 10^{-5} \mathrm{M}$

\section{$3 \cdot 2$ 錯形成率}

配位子 $\mathrm{L}_{1}$ 及び $\mathrm{L}_{2}$ と銅 (II) 並びにニッケル (II) イ オンとの DMF 中における錯形成率の時間変化を Fig. 5 に示す。なお錯形成率は近紫外部に認められる配位子 に基づく吸収帯の強度の娍少と，これら金属イオンとの 錯形成により新たに生じた吸収帯の強度の増大から求め た.いずれの配位子もニッケルイオンよりも銅イオンと の錯形成速度が著しく大きいことが分かる． $\mathrm{L}_{1}$ では 5 分後 $90 \%$ の錯形成率が得られ，その後 $100 \%$ 近くにな るのに対して， $\mathrm{L}_{2}$ では時間が経過しても錯形成率は $80 \%$ 以下であった. $3 \cdot 1$ の結果とも合わせて配位子 $\mathrm{L}_{1}$ をFIA 分析系へ応用した。

さて, 配位子 $\mathrm{L}_{1}$ は DMF などの有機溶媒に可溶であ るが，水に不溶である. 水溶液中の銅(II) イオンを分 析するためには有機溶媒-水の混合溶媒系を用いる必要 がある. 本研究では, 水と任意の割合で混合し, 誘電率 の高い DMF を有機溶媒として用いた. 又, 金属イオ ン水溶液の $\mathrm{pH}$ も一定にすることが望ましいので, ま ず配位子 $\mathrm{L}_{1}$ の DMF-水混合系における安定性について 検討した. Fig. 6 に DMF-緩衝水溶液系 $(9: 1)$ にお いて, 緩衝液の $\mathrm{pH}$ を変化させたときの吸収スペクト ルの変化を示す. pH 4 5 の領域では, DMF 単独溶液 とほぼ同様の吸収スペクトルを示すがこれより酸性側で は吸収極大波長は短波長側にシフトする。一方, $\mathrm{pH}$ を 6 以上にすると吸収極大波長は少しずつ長波長シフトし 吸収強度が低下する。これは, 低い $\mathrm{pH}$ 領域では配位 子の環内の窒素原子の一部がプロトン化するためであ り, 逆に高い $\mathrm{pH}$ 領域では加水分解により配位子の分 解が牛じるためであると考えられる.なお，DMF-水系

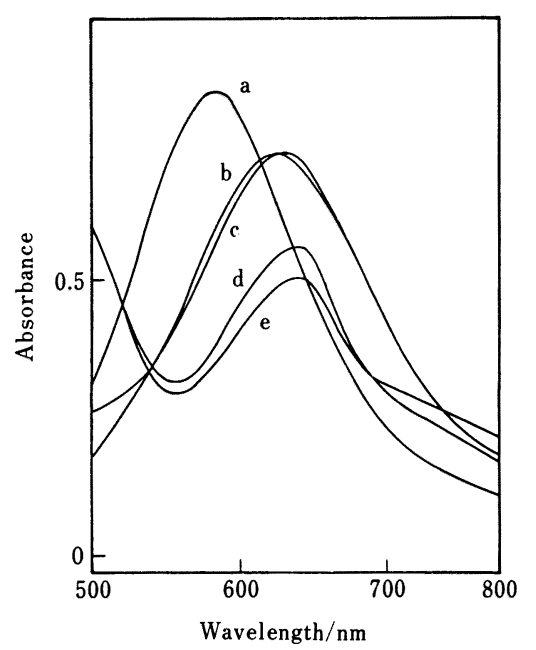

Fig. 6 Absorption spectra of $\mathrm{CuL}_{1}$ in mixed DMF-buffer solutions at different $\mathrm{pH}$ values $\mathrm{pH}: \mathrm{a}=3.0, \mathrm{~b}=4.0, \mathrm{c}=5.0, \mathrm{~d}=6.0, \mathrm{e}=7.0$

のため配位子 $\mathrm{L}_{1}$ の酸解離定数は求めていない. 次に, 銅(II) イオンの定量分析に用いる測定波長及び添加す る緩衝液の最適 $\mathrm{pH}$ 值を求めるために, バッチ法によ り緩衝液の $\mathrm{pH}$ を 5 の範囲で変化させ, 銅 $(\mathrm{II})$ イ オンとの錯形成による吸収スペクトルの時間変化を測定 した。試薬ブランクに対し，760 nm において最大の吸 光度差が得られたのでこれを测定波長とした，又，この 波長において吸光度の時間変化を検討したところ, 10 分経過後はいずれの $\mathrm{pH}$ 值においてもほぼ一定の值が 得られたので, より酸性側の $\mathrm{pH} 4.1$ の緩衝溶液を用い ることにした．更に，この条件で生成した銅錯体溶液の 吸光度は 1 時間経過後も一定值を保つことから, DMF-水系においても安定であることが分かった。

\section{3・3 Type I 法}

配位子 $\mathrm{L}_{1}$ (試薬) は水に不溶であり，DMF が $70 \%$ 以下の系を用いると沈殿するため, 試薬流量は常に緩衝 液より多く流す必要がある．そこで試薬流量を 0.25 か ら $0.5 \mathrm{ml} / \mathrm{min}$ まで変化させて緩衝液の流量と銅 $($ II $)$ イ オン注入によるピークの高さ (吸光度) により $U_{\mathrm{D}}=0.5$ $\mathrm{ml} / \mathrm{min}, U_{\mathrm{W}}=0.16 \mathrm{ml} / \mathrm{min}$ を最適条件とした。

得られた最適条件下で作成した検量線から, 配位子濃 度 $1 \times 10^{-4} \mathrm{M}$ で銅（II）イオン濃度 $1.1 \times 10^{-5} \mathrm{M}$ から $1.3 \times 10^{-4} \mathrm{M}$ まで相関係数 0.9998 と良好な直線関係が 得られた。この結果より配位子濃度以上の銅(II) イオ 
ンを定量していることから，錯形成が完全に行われてい ないことが推察される.そこで，これらの条件を更に改 良するためマージングゾーン法による検討を行った。

\section{3・4 Type II 法 (マージングゾーン法)}

試料注入後, 検出までに要する時間は DMF 溶液と 緩衝液の流量に反比例するが全体の $70 \%$ 以上を占める DMF 溶液の流量の影響が大きい。そこで, DMF 溶液 の流量を Type I 法で得た $U_{\mathrm{D}}=0.5 \mathrm{ml} / \mathrm{min}$ とし, 緩衝 液の流量を変化させて, ピークの高さ (吸光度) が最大 となる流量を求めたところ, $U_{\mathrm{W}}=0.1 \mathrm{ml} / \mathrm{min}$ を得た。

更に, DMF 溶液と緩衝液の流量に差があるため, 同時 に混合させるためには，両者の注人時間を変える必要が ある. 注入時間を変えて, ピークの高さ (吸光度) の最 大になる注入時間差を求めた。試薬の注人量, 銅(II) イオンを含む試料溶液の注入量, 反忍コイルの長さにつ いてそれぞれ検討した結果, 得られた最適条件を Table 1 にまとめて示す.これらの最適条件下で得られたフ ローダイヤグラムとそれから求めた検量線を Fig. 7 に

Table 1 Optimum conditions for determination of copper (II) by FIA (Type II)

\begin{tabular}{ll}
\hline $\begin{array}{l}\text { Concentration of reagent } \\
\text { Injection volume of reagent }\end{array}$ & $1 \times 10^{-4} \mathrm{M}$ \\
$\left(I_{\mathrm{D}}\right)$ & $200 \mu \mathrm{l}$ \\
Injection volume of sample & \\
$\left(I_{\mathrm{W}}\right)$ & $100 \mu \mathrm{l}$ \\
Injection time lag $(\Delta T)$ & $150 \mathrm{~s}$ \\
Flow rate $\left(U_{\mathrm{D}}\right)$ & $0.5 \mathrm{ml} / \mathrm{min}$ \\
Flow rate $\left(U_{\mathrm{W}}\right)$ & $0.1 \mathrm{ml} / \mathrm{min}$ \\
Reaction coil length $(R)$ & $200 \mathrm{~cm}$ \\
Detection wavelength & $760 \mathrm{~nm}$ \\
\hline
\end{tabular}
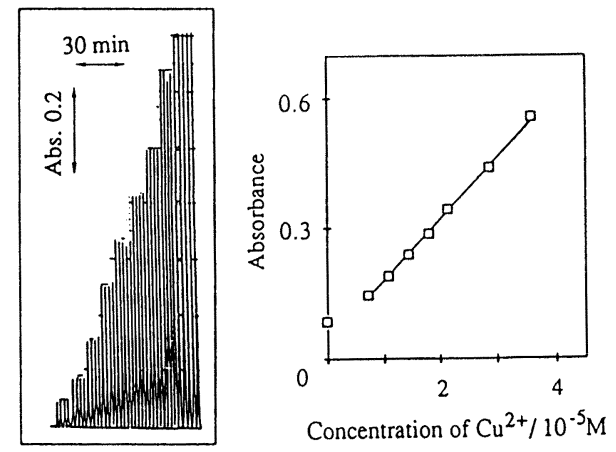

Fig. 7 Flow signals and calibration curve for determination of copper(II) (merging zone method)
Table 2 Effect of foreign ions on determination of copper (II)

\begin{tabular}{lcc}
\hline \multicolumn{1}{c}{ Added as } & \multicolumn{2}{c}{ Error, \% } \\
\cline { 2 - 3 } & FIA method & Batch method \\
\hline None & 0 & 0 \\
$\mathrm{MgCl}_{2}$ & 0.5 & 0.6 \\
$\mathrm{CaCl}_{2}$ & -0.1 & 0 \\
$\mathrm{Cr}(\mathrm{AcO})_{3}$ & 8.1 & -0.2 \\
$\mathrm{MnCl}_{2}$ & -8.8 & 0.6 \\
$\mathrm{Fe}_{2}\left(\mathrm{SO}_{4}\right)_{3}\left(\mathrm{NH}_{4}\right)_{2} \mathrm{SO}_{4}$ & -10 & 0 \\
$\mathrm{Co}\left(\mathrm{AcO}_{2}\right.$ & 1.0 & -4.2 \\
$\mathrm{Ni}(\mathrm{AcO})_{2}$ & 12.6 & 65.5 \\
$\mathrm{Zn}(\mathrm{AcO})_{2}$ & -11.4 & -13.3 \\
$\mathrm{~K}_{2} \mathrm{PdCl}$ & 1.2 & -6.1 \\
$\mathrm{Cd}(\mathrm{AcO})_{2}$ & -10.5 & -15.8 \\
$\mathrm{~K}_{2} \mathrm{PtCl}_{4}$ & -2.4 & 0.6 \\
$\mathrm{Hg}(\mathrm{AcO})_{2}$ & -10.9 & -8.5 \\
\hline
\end{tabular}

FIA method: $\left[\mathrm{Cu}^{2}\right]=3.57 \times 10^{-5} \mathrm{M}$, [Added ions] $=3.57 \times 10^{-5} \mathrm{M}$; Batch method: $\left[\mathrm{Cu}^{2}\right]=1.00 \times$ $10^{-5} \mathrm{M}$, [Added ions] $=1.00 \times 10^{-5} \mathrm{M}$

示す. 銅(II) イオン濃度 $7.1 \times 10^{-6} \mathrm{M}$ から $3.6 \times 10^{-5}$ M まで相関係数 0.9993 の良好な直線関係が得られた。 これはバッチ法によるものと同等の傾きを有している. なお原点を通らないのは試薬の吸収によるものである.

\section{3 -5 共存イオンの影穞}

配位子 $\mathrm{L}_{1}$ による共存イオン存在下における銅イオン の選択性について, FIA（Type II）法とバッチ法によ つて検討した結果を Table 2 に示す. 銅(II) イオンに 対して等モルの共存イオンを加えたときの銅イオンの吸 光度の変化を Error として表示した. この結果より，バ ッチ法では大きく妨害するニッケルイオンの影響はかな り小さくなっている.これは FIA 法では測定時間がバ ッチ法の 10 分と比べて 4 分以下と短く, ニッケルイオ ンの錯形成がほとんど起こらない間に測定されたことに よると考えられる.なお，バッチ法ではあまり誤差を生 じなかったクロム(III), マンガン(II) 及び鉄(III) イ オンの妨害が少し大きくなっているがこの原因について は不明である.

\section{文献}

1) Yu. A. Zolotov, V. P. Bodnja, G. A. Larikova, N. V. Niz'eva, G. E. Vlasova, E. V. Rybakova: $Z h$. Anal. Khim., 37, 1543 (1982).

2) Yu. A. Zolotov, N. V. Niz'eva, V. P. lonov, D. M. Kumina, O. V. lvanov: Mikrochim. Acta (Wien), 
1983 I, 381.

3) Yu. A. Zolotov, V. P. Ionov, N. V. Niz'eva, A. A. Formanovsky: Doki. Akad. Nauk SSSR, 1984, 277, 1145.

4) M. Fujiwara, T. Matsushita, 'T. Shono: Polyhedron, 3, 1357 (1984).

5) T. Matsushita, T. Takaishi, M. Fujiwara, T. Shono: Polyhedron, 6, 289 (1987).

6) M. Fujiwara, Y. Nakajima, T. Matsushita, T. Shono: Polyhedron, 4, 1589 (1985).

7) Y. Nakajima, M. Fujiwara, T. Matsushita, T. Shono: Polyhedron, 5, 1601 (1986).
8) M. Fujiwara, Y. Nakajima, T. Matsushita, T. Shono: Polyhedron, 4, 1859 (1985).

9) J. ltoh, T. Yotsuyanagi, K. Aomura: Anal. Chim. Acta, 74, 53 (1975).

10) 石井一, 高 英昌: 分析化学, 28, 473 (1979).

11) 四ツ柳隆夫: 化学, 35, 233 (1980).

12）伊藤純一, 小俣雅嗣, 岡宏: 分析化学, 37, T1 (1988).

13) T. Tokumitsu, T. Hayashi: Bull. Chem. Soc. Jpn., 54, 2348 (1981).

14) V. L. Goedken, M. C. Weiss: Inorg. Syn., 20, 115 (1980).

is

Application of the tetraaza macrocyclic Schiff base ligands bearing a chromophore to FIA of copper(II) ion. Manabu Fujiwara, Takayuki Matsushita*, Yuko YamashojI, Toru Morita, Seiji Tani, Minoru Tanaka and Toshiyuki Shono** ( ${ }^{*}$ Department of Materials Chemistry, Faculty of Science and Technology, Ryukoku University, Seta, Otsu-shi, Shiga 520-21; ${ }^{* *}$ Department of Applied Chemistry, Faculty of Engineering, Osaka University, Yamadaoka, Suita-shi, Osaka, 565)

Novel tetraaza macrocyclic Schiff base ligands $\left(\mathrm{L}_{1}\right.$ and $\left.\mathrm{L}_{2}\right)$ having a chromophore have been synthesized by reaction of 7-chloro-4-nitrobenzoxadiazole with the parent macrocyclic ligands, 5,7,12,14-tetramethyl-1,4,8,11-tetraazacyclotetradeca-1,5,7,12-tetraene and 6,8,15,17-tetramethyl-dibenzo-5,9,14,18-tetraazacyclotetradecene, respectively. These ligands have been found to complex selectively with a copper(II) ion. Under optimal complexation conditions, $\mathrm{L}_{1}$ afforded a higher molar extinction coefficient $(\log \varepsilon=4.22)$ than $\mathrm{L}_{2}$, so that $\mathrm{L}_{1}$ has been applied to a spectrophotometric reagent for the determination of copper(II) ion by FIA. Two systems, a parallel flow method and a merging zone method, have been examined and the latter has been found to be superior to the former. This is due to that the complexation is less complete in the former than in the latter case. Although the sensitivity to the copper(II) ion obtained under the optimal conditions is comparable to that obtained in a batch system, the method exhibits advantages such as less interference from nickel(II) ion during the determination and shortening of the time required for the determination.

(Received December 11, 1990)

\section{Keyword phrases}

tetraaza macrocyclic Schiff base; FIA determination of copper(II); spectrophotometric reagent. 